\title{
First Visit Seen
}

National Cancer Institute

\section{Source}

National Cancer Institute. First Visit Seen. NCI Thesaurus. Code C159696.

An indication of the first visit during which a particular event or status was noted. 